\title{
Development of Instant Curry Paste from Coconut Kernel
}

\author{
K.N. Satheeshan ${ }^{1 *}$, B.R. Seema ${ }^{2}$ and A.V. Meera Manjusha ${ }^{1}$ \\ ${ }^{1}$ Department of Horticulture, Regional Agricultural Research Station, Pilicode, Kerala \\ Agricultural University - 671310, Kerala, India \\ ${ }^{2}$ Center of excellence in Post Harvest Technology, Regional Agricultural Research Station, \\ Pilicode, Kerala Agricultural University-671310, Kerala, India \\ *Corresponding author
}

\section{A B S T R A C T}

A study is conducted at the Regional Agricultural Research Station, Pilicode for developing an instant curry paste with coconut kernel as base material which is in line with

Keywords

Curry paste, Virgin

coconut oil,

Coconut, Starch,

Microbial analysis,

Sensory analysis

Article Info

Accepted:

04 June 2019

Available Online:

10 July 2019 a traditional cuisine in Malabar region of Kerala. Spicy curry paste from desiccated coconut was prepared without any preservatives using virgin coconut oil, salt, curry leaf, guar gum, papaya starch, tapioca starch, jack fruit seed flour, onion powder and garlic powder along with an ideal blend of spices for instant, easy and fast cooking. Spices were used in seven different combinations and proportions in both sambar and chicken curry paste and its consumer acceptability was investigated. All the samples were assessed for proximate compositions and quality changes in the curry paste stored at ambient temperature for 90, 180 and 360 days were monitored. Shelf life study indicated that the samples could be stored for one year or more without spoilage even in the absence of preservatives. Considering the results obtained in sensory analysis, a combination of sambar curry paste: jack fruit seed flour: onion powder: garlic powder: guar gum in the ratios of 91.5:0.5:1.5:1.5:0.5 was adjudged as best for sambar curry paste, while a combination of chicken curry paste: papaya starch: onion powder: garlic powder: guar gum in the ratios of $91.5: 0.5: 1.5: 1.5: 0.5$ was selected as the best combination for chicken curry paste which could be recommended for commercial production.

\section{Introduction}

Coconut and spices are inseparable components of a wide range of Kerala/south Indian cuisine. It is the age old tradition of Keralites to use coconut kernel, both fresh and roasted, for making culinary preparations to enhance the taste and flavor especially for non-vegetarian delicacies like fish and meat preparations. This unique practice also imparts a thickness to the gravy. The distinct flavor and appearance of Malabar fish curry is mainly attained from the paste of coconut kernel and an ideal blend of spices added to it during preparation. This is a signature dish in many Kerala home.

Coconut curry paste is a convenient food based on traditional Kerala cuisine for easy and fast cooking. It consists of coconut meat, virgin coconut oil, green chilly, red chilly powder, curry leaf, spices (garlic, small onion, 
ginger, turmeric, coriander, cumin, fenugreek, asafoetida, tamarind) and salt all blended together to obtain a homogeneous dark-brown paste. It provides the colour, spice taste and authentic fragrance for certain Kerala dishes.

The spices /ingredients used in the curry paste may differ from home to home or region to region. Spices have very low calorie content and are reliable sources of antioxidants and other potential bioactive compounds in diet (Muthulakshmi et al., 2009). Due to their phenol content these are able to block the formation of compounds that contribute to damage caused by metabolic disorders. Spices possess many pharmacological properties and find essential application in the preparation of ayurvedic medicines, in preventing and treating a wide variety of diseases such as cancer, ageing, and metabolic, neurological and cardiovascular diseases (Gottardi et al., 2016). So we can curtail several health disorders by adding them in our day to day dietary intake.

On an analysis from a dietary perspective, the functionality of coconut, virgin coconut oil and spices are well documented. Coconuts have been used in traditional medicine around the world to treat numerous ailments, ranging from sore throat, colds, and ear aches to tuberculosis, tumors, and ulcers. Recent medical studies have found that coconut can have antibacterial, antifungal, anthelmintic, and antiviral properties, among other health benefits.Virgin coconut oil (VCO), which may be produced from fresh coconut meat, coconut milk or coconut milk residue is rich in medium-chain triglycerides and lauric acid. It has been widely consumed as a health food having antiulcerogenic, anti-nociceptive, anti-inflammatory, anti hypercholesterolemic, antimicrobial and hepato protective effects (Kamariah et al., 2008, Zakaria and Somchit, 2011).
Spices used in the curry paste are typically: turmeric, ginger and chilli which are sources of phytochemicals or bioactive compounds which are claimed to prevent non-contagious diseases such as high blood pressure, diabetes and cancer (Kaefer and Milner, 2008). Turmeric is useful in healing wounds and is frequently used in traditional ayurvedic preparations. It has been reported to have has anti-inflammatory, anti-diabetic and anticancerous properties and counteract several disorders (Swamy et al., 2012). It also reduces cholesterol and triglyceride concentrations. Curcumin present in the turmeric shows a wide range of pharmacological properties including antimicrobial, antioxidant, antiinflammatory, and anticancer (Miquel et al., 2002) Ginger is used in many countries as a spice and condiment to add flavor to food (Park et al., 2002). It has staring potential for treating a number of ailments including degenerative disorders (arthritis and rheumatism), digestive health, cardiovascular disorders, vomiting, diabetes mellitus, and cancer. Furthermore, it has antimicrobial potential as well which can help in treating infectious diseases (Shukla and Singh, 2007). Chilly provides strong pungency and aroma flavor and have antimutagenic or anticarcinogenic properties.

Coriander has traditionally been referred to as an "anti-diabetic" plant. In some parts of India, it has traditionally been used for its antiinflammatory properties. In the United States, coriander has reported for its cholesterol lowering effects (Msaada et al., 2007). Garlic (Allium sativum L.) has acquired a reputation in different traditions as a prophylactic as well as therapeutic plant. Shallot is normally recognized for its hypocholesterolemic and antimicrobial effects. Therefore, curry paste might be considered as a functional food.

Jackfruit is one of the most significant evergreen trees in tropical areas and widely 
grown in Asia including India. The jackfruit seeds are used in cooked dishes and its flour is used for baking. Jackfruit seeds are fairly rich in starch and contain thiamin and riboflavin which gives energy and keeps eyes, skin and hair healthy. It also provides small amounts of minerals like zinc, iron, calcium, copper, potassium and magnesium. It contains compounds that have an antimicrobial effect, which could help prevent contamination with bacteria that cause food borne illnesses. These seeds have also been used in traditional medicine to help with digestive tract problems (Singh et al., 1991). Tapioca is a starchy product derived from cassava plant. Like other starches, it is mainly carbohydrates and contains lower amount of protein, vitamins and trace amount of fat. It contains high amount of fibre helps in lowering the risk of colon cancer, diabetes and heart disease. Papayas are rich sources of antioxidant nutrients such as carotenes, vitamin $\mathrm{C}$ and flavonoids, vitamin $\mathrm{B}$, folate and pantothenic acid and minerals, potassium, copper, magnesium and fiber. Together, these nutrients promote the health of the cardiovascular system and also provide protection against colon cancer.

Considering the benefits of different raw materials namely coconut meat, virgin coconut oil, green chilly, red chilly powder, curry leaf, salt, blends of spices and starches will ensure a food which is safe to consume, nutritious and convenient. The process of preparation of coconut paste from the gratings and mixing it up with adequate quantities of spices is cumbersome and time consuming as roasting and grinding demand more time and effort. This offers enough scope for development for products such as instant curry pastes that offer a time and effort advantage over traditional cooking practices. Such products also have the advantage that they can be stored for a period of more than one year without employing cold chain.
So by keeping these points in view a study was undertaken to evolve recipes for instant curry paste for sambar and chicken with authentic taste without addition of class II preservatives. The objective of the study also involves assessing the consumer acceptance, stability, proximate composition and keeping quality with respect to microbial load and extended long term storage life.

\section{Materials and Methods}

\section{Materials}

The raw materials selected for development of sambar curry paste consists of coconut, virgin coconut oil (VCO), garlic, shallots, ginger, red chilli, coriander, cumin, turmeric, green chilly, fennel, fenugreek, asafoetida, tamarind, curry leaf and salt. For chicken curry paste, the ingredients are coconut, virgin coconut oil, garlic, shallots, red chilly, ginger, pepper, coriander, cumin, clove, turmeric, green chilly, curry leaf and salt. Coconut (Cocos nucifera), VCO, curry leaf (Murraya koenigii), ginger (Zingiber officinale), green chilly (Capsicum annum L), were collected from RARS, Pilicode, Kasargod, Kerala and shallot/small onion (Allium cepa var. aggregatum L.), garlic (Allium sativum) and the remaining raw materials were procured from nearby super market.

Freshly harvested tapioca, papaya and jackfruit seeds were procured from farm, cleaned with water to remove the surface dirt. Above raw materials were cleaned, peeled, sliced using a slicer and blanched with hot water $\left(100^{\circ} \mathrm{C}\right.$ for 3 minutes) and all these were dried in a cabinet dryer at $70^{\circ} \mathrm{C}$ for $4 \mathrm{~h}$. Similarly onion and garlic were cleaned peeled and dried using drier. The above said raw materials were pulverized in a hammer mill and sieved manually using ISS 35 mesh in order to obtain flour of uniform particle size. The flours of tapioca, papaya and 
jackfruit were used as starch, onion and garlic powder used as stabilizing /emulsifying agent and guar gum used as thickening agent in preparation of curry paste.

The above raw materials were blended in seven different combinations and proportions in both sambar and chicken curry paste. These blends were chosen according to preliminary tests for acceptable taste. Various combination used for sambar and chicken curry paste are described in Table 1 and 2 respectively.

\section{Preparation of curry paste}

All fresh spices were sorted, trimmed, washed, drained for $2 \mathrm{~min}$, sliced, weighed according to the recipe. Coconut kernel with garlic and multiplier onion was fried without using coconut oil. All the spices were fried in little amount of oil and ground separately. Fried coconut, garlic and multiplier onion is again fried with the remaining oil and add ground spices, salt and coriander powder.

The mixture was mixed well using mixer grinder till it obtained a homogeneous darkbrown paste like consistency. Then paste was kept in to a cleaned vessel for to settle and the extra oil present in it was decanted. Repeat decantation process for 3 days. The paste was aseptically sampled, sealed in a sterilized glass bottles and stored at ambient conditions. No preservatives and colour was added to curry paste. After standardization of recipe, samples were prepared by adding starches of tapioca, papaya, jackfruit seed flour, onion and garlic powder as a stabilizing/emulsifying agent and edible guar gum for consistency, body formation, and texture after reconstitution of mix.

\section{Sensory evaluation of cooked curry paste}

Chicken and sambar curry were prepared with the selected process protocol by incorporating the respective prepared curry paste into it before serving to sensory panel.

A semi-trained panel of 12 judges evaluated the prepared products for colour \& appearance, flavour, taste, texture and overall acceptability on a 9-point hedonic scale.

\section{Proximate composition of developed curry paste}

\section{Moisture content (\%)}

The hot air oven method (AOAC, 2005) was used to determine the moisture content of samples.

\section{Protein $(g / 100 g)$}

Protein estimation was done by the method described by Lowry (1951).

\section{Crude fat $(\%)$}

Determination of crude fat was done by the method described by Mattoo (1970) and Lowry et al., (1951).

\section{Crude fibre (\%)}

Crude fibre was determined by using the method given by Maynard (1970).

\section{Ash (\%)}

Determination of ash was done based on AOAC (2000) standard method.

pH

amples were blended with sterilized distilled water at the ratio of 1:5 (sample:water) and allowed to dissolved for $2 \mathrm{~min}$. and $\mathrm{pH}$ measured with a $\mathrm{pH}$ meter (Systronics, $\mu \mathrm{pH}$ system-362). 


\section{Storage studies}

The developed curry paste were stored in glass bottles in replicated kits upto twelve months. The microbial analysis was carried out at intervals of fresh, 3 months, 6 months and 12 months for testing the microbial load and shelf life after the respective storage periods.

\section{Analysis of microbial population in curry paste}

One gram of sample was weighed and transferred aseptically to $9 \mathrm{ml}$ of sterile distilled water to get $10^{-1}$ dilution and mixed well. From $10^{-1}$ dilution, one $\mathrm{ml}$ of aliquote was transferred to another test tube containing $9 \mathrm{ml}$ sterile distilled water to get $10^{-2}$ dilution. Then this procedure was repeated upto $10^{-5}$ dilution.

One $\mathrm{ml}$ of aliquot from different dilution was transferred to sterile petri plates for the enumeration of bacteria and triplicates were taken. Poured 15-20 ml of appropriate growth media (nutrient agar for bacteria) at temperature $\left(45-50^{\circ} \mathrm{C}\right)$ and the plates were rotated clockwise and anticlockwise directions on the flat surface to have a uniform distribution of colonies. After the solidification of agar, the plates were inverted and incubated at room temperature for 2-5 days (bacteria for one day, yeast and fungi for three days). Total plate counts (TPC) were determined on plate count agar pour plates and enumerated after an incubation period of 48$72 \mathrm{~h}$ at $30^{\circ} \mathrm{C}$. The colonies were counted after the incubation period and the number of cfu per ml of sample were calculated by applying the following formula:

Number of colony forming units per $\mathrm{ml}$ of the sample

No. of $\mathrm{cfu} / \mathrm{ml}=\frac{\text { Mean number of of } \mathrm{X} \text { dilutiopn factor }}{\text { vol of thr sample }}$

\section{Statistical analysis}

Completely randomised design (CRD) was adopted for analysing the data by using WASP and Design - Expert software version 7.0.0 (Statease Inc., Minneapolis, USA). Statistical significance was examined by analysis of variance (ANOVA) for each response.

\section{Results and Discussion}

The experimental results obtained from the present study have been discussed in the following headings:

\section{Proximate composition}

The proximate composition namely, moisture content, protein, crude fat, crude fibre, ash and $\mathrm{pH}$ for all the combinations of curry paste were determined and observations are detailed in Table 3.

\section{Moisture content (\%)}

Moisture content of both sambar and chicken curry paste was found to be in the range of 0.18 to 0.31 ad 0.07 to $0.34 \%$ respectively. Similar results were recorded by Karadbhajne and Saraf (2017) for instant curry mix for vegetarian recipes. The moisture content recorded for all the combination was found to be safe for storage.

\section{Protein $(g / 100 g)$}

Protein content of sambar and chicken curry paste varied between 2.0 to 6.1 and 2.0 to 5.5 $\mathrm{g} / 100 \mathrm{~g}$ respectively. Similar results were recorded by Gunathllakel and Bandara (2005) for preparation of the ready-to-use coconut cum spices paste $(6.71 \mathrm{~g} / 100 \mathrm{~g})$. The highest protein content in sambar curry paste was observed in T5 combination which is fortified with 5\% papaya starch and the lowest was recorded in T3 combination. In case of 
chicken curry paste, highest protein was found to be in $7.5 \%$ papaya starch incorporated sample and lowest in T0 combination. Consequently, using ready to use curry paste rather than a spice mix plus coconut milk extracted from scraped coconut, would increase the quality and quantity of protein and crude fibre in the curry adding its nutritional value.

\section{Crude fat (\%)}

Fat content was maximum in $\mathrm{T} 0(57.27 \%)$ and T6 $(53.76 \%)$ and minimum in T6 $(45.99 \%)$ and T4 $(30.2 \%)$ of sambar and chicken curry paste respectively. This fat content of curry paste is derived mainly from the coconut oil used in its preparation. Since coconut fat is saturated, product contains low amount of moisture. Similar results were recorded by Gunathllakel and Bandara (2005) for preparation of the ready-to-use coconut cum spices paste $(56 \%)$.

\section{Crude fibre (\%)}

It was observed that, there was no fibre content in T1, T3, T5 combinations of sambar and T0, T3, T5 combinations of chicken curry paste. Highest fibre content was found in T0 $(0.35 \%)$ of sambar and T2 and T6 $(0.05 \%)$ chicken curry paste.

\begin{tabular}{|c|l|c|c|c|c|c|c|c|}
\hline \multicolumn{9}{|c|}{ Table.1 Raw materials used to prepare seven blends of sambar curry paste } \\
\hline SI No. & \multicolumn{1}{|c|}{ Ingredients $(\%)$} & Combinations \\
\cline { 3 - 10 } & & T0 & T1 & T2 & T3 & T4 & T5 & T6 \\
\hline $\mathbf{1}$ & Sambar Curry paste $\left(\mathrm{C}_{\mathrm{p}}\right)$ & 100 & 90 & 92.5 & 95.5 & 91.5 & 91.5 & 91.5 \\
\hline $\mathbf{2}$ & Jackfruit seed flour $\left(\mathrm{J}_{\mathrm{f}}\right)$ & - & 10 & - & - & 5 & - & - \\
\hline $\mathbf{3}$ & Papaya starch $\left(\mathrm{P}_{\mathrm{s}}\right)$ & - & - & 7.5 & - & - & 5 & - \\
\hline $\mathbf{4}$ & Tapiaco starch $\left(\mathrm{T}_{\mathrm{s}}\right)$ & - & - & - & - & - & - & 5 \\
\hline $\mathbf{5}$ & Onion powder $\left(\mathrm{O}_{\mathrm{p}}\right)$ & - & - & - & 2 & 1.5 & 1.5 & 1.5 \\
\hline $\mathbf{6}$ & Garlic powder $\left(\mathrm{G}_{\mathrm{p}}\right)$ & - & - & - & 2 & 1.5 & 1.5 & 1.5 \\
\hline $\mathbf{7}$ & Guar gum $(\mathrm{G})$ & - & - & - & 0.5 & 0.5 & 0.5 & 0.5 \\
\hline
\end{tabular}

\begin{tabular}{|c|l|l|l|l|l|l|r|r|}
\hline \multicolumn{9}{|c|}{ Table.2 Raw materials used to prepare seven blends of chicken curry paste } \\
\hline Sr. No. & \multicolumn{1}{|c|}{ Ingredients $(\%)$} & \multicolumn{7}{c|}{ Combinations } \\
\cline { 4 - 10 } & & T0 & T1 & T2 & T3 & T4 & T5 & T6 \\
\hline $\mathbf{1}$ & Chicken Curry paste $\left(\mathrm{C}_{\mathrm{p}}\right)$ & 100 & 90 & 92.5 & 95.5 & 91.5 & 91.5 & 91.5 \\
\hline $\mathbf{2}$ & Jackfruit seed flour $\left(\mathrm{J}_{\mathrm{f}}\right)$ & - & - & - & - & - & - & 5 \\
\hline $\mathbf{3}$ & Papaya starch $\left(\mathrm{P}_{\mathrm{s}}\right)$ & - & - & 7.5 & - & - & 5 & - \\
\hline $\mathbf{4}$ & Tapioca starch $\left(\mathrm{T}_{\mathrm{s}}\right)$ & - & 10 & - & - & 5 & - & - \\
\hline $\mathbf{5}$ & Onion powder $\left(\mathrm{O}_{\mathrm{p}}\right)$ & - & - & - & 2 & 1.5 & 1.5 & 1.5 \\
\hline $\mathbf{6}$ & Garlic powder $\left(\mathrm{G}_{\mathrm{p}}\right)$ & - & - & - & 2 & 1.5 & 1.5 & 1.5 \\
\hline $\mathbf{7}$ & Guar gum $(\mathrm{G})$ & - & - & - & 0.5 & 0.5 & 0.5 & 0.5 \\
\hline
\end{tabular}




\begin{tabular}{|c|c|c|c|c|c|c|c|c|c|c|c|c|}
\hline & & Table.3 & Quality & parame & ters of & sambar & and chi & ken cur & ry past & & & \\
\hline \multirow[t]{2}{*}{ Treatments } & \multicolumn{2}{|c|}{$\begin{array}{l}\text { Protein } \\
(\mathrm{g} / \mathbf{1 0 0 g})\end{array}$} & \multicolumn{2}{|c|}{$\begin{array}{c}\text { Moisture } \\
(\%)\end{array}$} & \multicolumn{2}{|c|}{$\begin{array}{c}\text { Crude fat } \\
(\%)\end{array}$} & \multicolumn{2}{|c|}{$\begin{array}{c}\text { Crude fibre } \\
(\%)\end{array}$} & \multicolumn{2}{|c|}{$\operatorname{Ash}(\%)$} & \multicolumn{2}{|c|}{ pH } \\
\hline & SCP & CCP & SCP & $\mathrm{CCP}$ & SCP & $\mathrm{CCP}$ & SCP & $\mathrm{CCP}$ & SCP & $\mathrm{CCP}$ & SCP & CCP \\
\hline T0 & 3.7 & 3.5 & 0.18 & 0.34 & 57.27 & 48.98 & 0.35 & Nil & 5.94 & 7.85 & 4.86 & 5.42 \\
\hline T1 & 4 & 2 & 0.3 & 0.34 & 52.61 & 46.18 & NIL & 0.2 & 7.5 & 8.49 & 4.89 & 5.42 \\
\hline T2 & 4.3 & 5.5 & 0.28 & 0.32 & 49.25 & 46.73 & 0.05 & 0.05 & 9.07 & 8.53 & 4.97 & 5.42 \\
\hline T3 & 2 & 2.1 & 0.32 & 0.31 & 50.99 & 33.79 & NIL & Nil & 7.04 & 9.89 & 4.87 & 5.49 \\
\hline T4 & 3.7 & 3 & 0.26 & 0.18 & 51.14 & 30.2 & 0.05 & 0.3 & 6.45 & 6.91 & 4.92 & 5.44 \\
\hline T5 & 6.1 & 5.1 & 0.31 & 0.07 & 55.03 & 50.02 & NIL & Nil & 7.32 & 8.23 & 4.93 & 5.36 \\
\hline T6 & 2.9 & 4.6 & 0.32 & 0.09 & 45.99 & 53.76 & 0.15 & 0.05 & 9.66 & 9.1 & 4.96 & 5.41 \\
\hline $\begin{array}{c}\text { Coefficient } \\
\text { of } \\
\text { variation }\end{array}$ & 10.675 & 12.137 & 6.771 & 6.373 & 3.353 & 0.337 & 18.552 & 48.643 & 3.268 & 1.507 & 7.937 & 2.337 \\
\hline$P$ value & 0.000 & 0.000 & 0.000 & 0.000 & 0.000 & 0.000 & 0.000 & 0.003 & 0.000 & 0.000 & 0.997 & 0.93 \\
\hline CD (0.01) & 0.984 & 1.080 & 0.042 & 0.037 & 4.218 & 0.358 & 0.072 & 0.198 & 0.601 & 0.302 & & \\
\hline CD (0.05) & 0.719 & 0.782 & 0.033 & 0.024 & 3.045 & 0.258 & 0.054 & 0.133 & 0.431 & 0.221 & & \\
\hline
\end{tabular}

Sensory scores - Sambar curry paste

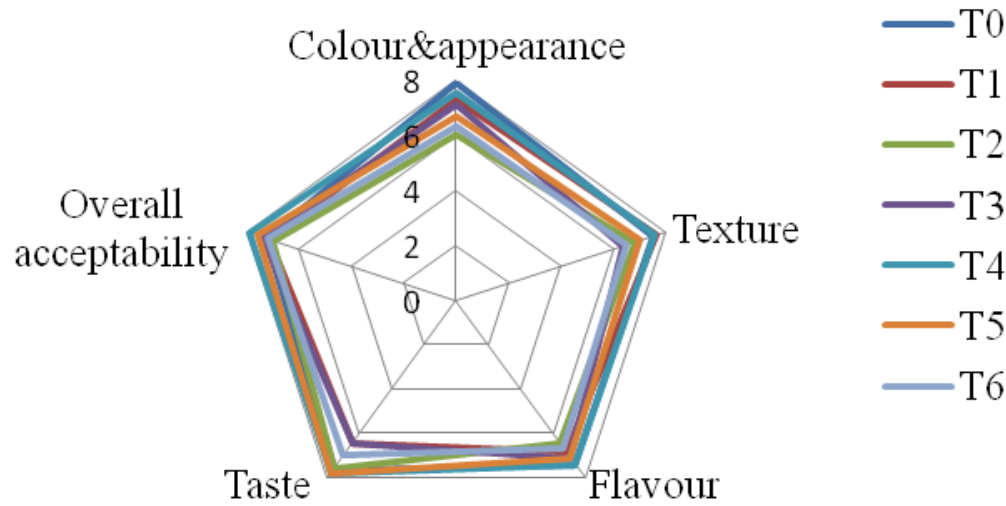

Fig. 1 Sensory scores for sambar curry paste 


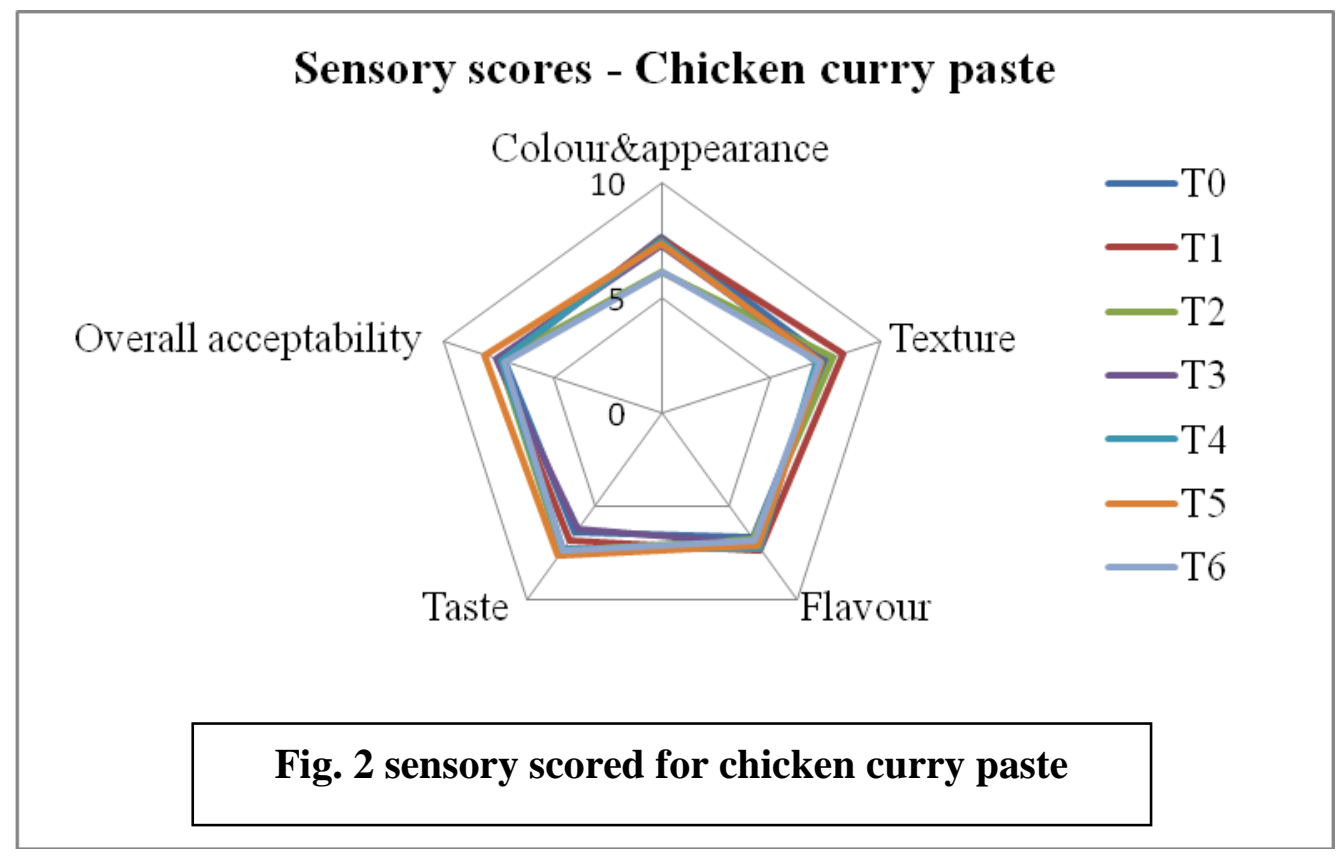

\section{Ash (\%)}

Ash content of both sambar and chicken curry paste was found to be in the range of 5.94 to 9.66 and 6.91 to $9.89 \%$ respectively.Statistical analysis showed that combinations of different raw materials have significant $(p<0.0001)$ effect on proximate composition of curry paste.

\section{pH}

The $\mathrm{pH}$ was calculated for all samples and it was observed that, the $\mathrm{pH}$ of sambar curry paste was minimum for T0 (4.86) and maxiumum for $\mathrm{T} 2$ (4.97). $\mathrm{pH}$ of chicken curry paste was found to be in the range of 5.36 to 5.49. Thus the curry paste may be classified as low acid food. The observed values were in agreement with the trend reported by Siripong vutikorn et al., (2008) for green curry paste marinade for white shrimp.

\section{Microbial analysis for best judged curry paste}

The microbial analysis was carried out for the best judged sambar and chicken curry paste during storage period. The microbial analysis for T4 of sambar curry paste was found safe (TPC $2.56 \times 10^{5} \mathrm{cfu} / \mathrm{g}$ ) for the storage period of twelve months. Similarly, best combination of T5 of chicken curry paste also found safe (TPC $3.94 \times 10^{5} \mathrm{cfu} / \mathrm{g}$ ) for twelve month storage period.

The maximum permissible microbial limits of aerobic colony count for ready to eat food ranges from $10^{5}$ to less than $10^{6} \mathrm{cfu} / \mathrm{g}$ (Anon., 2007). The results showed that there was no contamination in both sambar and chicken curry paste during storage period and the product was found to be microbial safe.

\section{Sensory evaluation}

The panels of judges consisting of 12 members were given the developed samples for evaluation of organoleptic characteristics viz. colour and appearance, flavour, taste, texture and overall acceptability. The average score recorded by the judges was considered, presents (Fig. 1 and 2) and discussed. Overall acceptability of the product varies from 7.03 to 7.95 and 7.19 to 8.12 in sambar and chicken curry paste respectively. The mean 
scores of sensory evaluation showed that all the samples prepared from Virgin coconut oil, salt, curry leaf, guar gum, papaya starch, tapioca starch, jack fruit seed flour, onion powder, garlic powder and an ideal blend of spices were in acceptable range, while the sample T4 of sambar and T5 of chicken curry paste were best accepted by the sensory panel. It was revealed from the scores of the overall acceptability that the starch can be successfully mixed to prepare a better acceptable product.

Attempts were made to develop a curry paste which would have maximum score in sensory evaluation so as to get better market acceptability, minimum moisture content, maximum protein, crude fibre, crude fat, and ash. The response was predicted by the Design - Expert software. Under these criteria, based on optimization and sensory evaluation, T4 of sambar curry paste i.e., sambar curry paste: jack fruit seed flour: onion powder: garlic powder: guar gum in the ratios of 91.5:05:1.5:1.5:0.5 and $\mathrm{T} 5$ of chicken curry paste i.e., chicken curry paste: papaya starch: onion powder: garlic powder: guar gum in the ratios of 91.5:05:1.5:1.5:0.5 was selected as a best combination which could be recommended for the market.

Convenience foods made of coconut based curry preparations are scanty in the market at present. A lot of opportunities lie ahead for this kind of products for export and upcountry markets besides individual local/urban customers, restaurants, canteens and catering service etc.

These products could satisfy the needs of fast food joints, restaurants and housewives and would also have export market especially among ethnic groups leading to a potential money spinner.

\section{References}

Anonymous. 2007. Microbial guidelines for ready to eat food: The Centre for Food Safety, Food and Environmental Hygiene Department. Hong Kong.

AOAC (2000) Official Methods of Analysis. 17th Edition, the Association of Official Analytical Chemists, Gaithersburg, MD, USA.

Association of Official Analytical Chemists (AOAC), 2005. Official Methods of Analysis of the AOAC International. $18^{\text {th }}$ edn. Gaithersburg, MD, USA.

Gottardi, D., Bukvicki, D., Prasad, S. and Tyagi, A.K. 2016. Beneficial effects of spices in food preservation and safety. Frontiers in Microbiology. Vol 7, Review published: 21 September 2016 doi: 10.3389/fmicb.2016.01394.

Gunathllakel, K.D.P.P. and Bandara, A.G.A. 2005. Preparation of a ready-to-use coconut cum spices paste for chicken curry and evaluation of its physicochemical and storage properties. COCOS. 17: 21-29.

Kaefer, C.M. and Milner, J.A. 2008. The role of herbs and spices in cancer prevention. The Journal of Nutritional Biochemistry 19(6):347-361.

Kamariah, L., Azmi, A., Rosmawati, A., WaiChing, M.G., Azlina, M.D., Sivapragasam, P., Tan, C.P. and Lai, O.M. 2008. Physico-chemical and quality characteristics of virgin coconut oil - a Malaysian survey. J Trop Agric. FoodSci 36: 239-248.

Karadbhajne, S.V. and Saraf, N.A. 2017. Determination of physical, chemical and sensory characteristics of instant curry mix for vegetarian recipes. Int. J. Food Sci. Nutri. 2 (6): 181-186.

Lowry, O.H., Rosebrough, N.J., Farr, A.L. and Randall, R.J. 1951. J. Biol. Chem 193: 265. 
Mattoo, R.L. 1970. Influence of sodium chloride on the colorimetric determination of protein in plant tissues rich in phenols-phenolases. Indian $\mathbf{J}$ Biochem.7: 82-83.

Maynard, A.J (Ed). 1970. Methods in Food Analysis Academic Press New York p 176.

Miquel, J., Bernd, A., Sempere, J.M., DíazAlperi, J. and Ramírez, A. 2002. The curcuma antioxidants: pharmacological effects and prospects for future clinical use. A review. Arch Gerontol Geriatr. 34(1):37-46.

Msaada, K., Hosni, K., Taarit, M.B., Chahed, T., Kchouk, M.E. and Marzouk, B. 2007. Changes on essential oil composition of coriander (Coriandrum sativum $L$.) fruits during three stages of maturity. Food Chem. 102: 1131-34.

Muthulakshmi, V., V. Vijayakumar, M. Vasanthkumar and H.R. Vasanthi, 2009. In: Functional Foods for Chronic Diseases. Danik M. Martirosyan., editor. Vol. 4. D \& A Inc/FF Publishing, pp: 274-317.
Park, E.J, and Pizzuto, J.M. 2002. Botanicals in cancer chemoprevention. Cancer Metast Rev. 21:231-55. [PubMed]

Shukla, Y, and Singh, M. 2007. Cancer preventive properties of ginger: A brief review. Food Chem. Toxicol. 45: 68390.

Singh, A., Kumar, S. and Singh, I.S. 1991. Functional properties of jackfruit seed flour. Lebensm - Wissu Technol 24:373-4.

Siripongvutikorn, S., Pengseng, N., Ayusuk, S. and Usawakesmanee, W. 2008. Development of green curry paste marinade for white shrimp (Litopenaeusvannamei). 30: 35-40.

Swamy, A.V., Gulliaya, S., Thippeswamy, A., Koti, B.C and Manjula, D.V.2012. Cardioprotective effect of curcumin against doxorubicin-induced myocardial toxicity in albino rats. Indian $J$ Pharmacol.44:73-77.

Zakaria, Z.A. and Somchit M.N. 2011. In vivo antinociceptive and anti-inflammatory activities of dried and fermented processed virgin coconut oil. Med Princ Pract. 20: 231-236.

\section{How to cite this article:}

Satheeshan, K.N., B.R. Seema and Meera Manjusha, A.V. 2019. Development of Instant Curry Paste from Coconut Kernel. Int.J.Curr.Microbiol.App.Sci. 8(07): 187-196.

doi: https://doi.org/10.20546/ijcmas.2019.807.024 